\title{
Relationship between organizational climate and management effectiveness
}

\author{
Article history: \\ Received: 6 July 2016 \\ Sent for revision: 28 August 2016 \\ Received in revised form: 24 January 2017 \\ Accepted: 24 January 2017 \\ Available online: 5 April 2017
}

\begin{abstract}
The subject of this research is the connection between management effectiveness in economic organizations of Vojvodina and creative organizational climate. According to that, scientific objective of our research is checking one of the most widely used model of measuring management effectiveness - Baldrige's model, on which is based system of management quality incentives in USA. Problem of this research can be expressed with following questions: Whether is possible that the company management in modern market conditions in AP Vojvodina, which has been designed as per traditional Taylor's model that started from the early stage of capitalism development, can be considered as effective? The key finding of this study can be expressed by the following conclusion: in a sample of observed organization the level of organizational creativity is at zero level. Ideas and behaviors inherent to creative organizational climate only born (average rating of level of creativity that all surveyed respondents gave was 0.396, and the median is 0.428). In an effort to concretize this finding, correlation analysis was undertaken between grouped variables of organizational creativity and potential factorial variables of organizational creativity.
\end{abstract}

Keywords: creativity, organisational effectivity, creative organisational climate

\footnotetext{
${ }^{1}$ University Union - Nikola Tesla, Faculty and business study and law, Belgrade, olja.arsenijevic@fpsp.edu.rs

2 ALFA BK University, Belgrade

${ }^{3}$ University Union - Nikola Tesla, Faculty and business study and law, Belgrade 
Arsenijević O. et al.: Relationship between organizational climate and management...

\title{
Odnos između organizacione klime i efektivnosti menadžmenta
}

\begin{abstract}
Apstrakt: Predmet ovog istraživanja predstavlja povezanost efektivnosti menadžmenta privrednih organizacija Vojvodine sa kreativnom organizacionom klimom.Shodno tome, naučni cilj nešeg istraživanja je provera jednog od najšire korišćenih modela merenja efektivnosti menadžmenta - Baldridžovog modela, na kojem se zasniva sistem podsticanja kvalitata menadžmenta u SAD. Problem ovog istraživanja možemo formulisati pitanjima: Može li se u savremenim tržišnim okolnostima menadžment preduzeća u AP Vojvodini, oblikovanim prema tradicionalnom tejlorističkom modelu proisteklom iz ranih etapa razvoja kapitalizma, smatrati efektivnim? Ključni nalaz ovog istraživanja može se iskazati sledećim zaključkom: u uzorku posmatranih organizacija nivo organizacione kreativnosti je na nultom nivou. Ideje i ponašanja svojstvena kreativnoj organizacionoj klimi tek se rađaju (prosečna ocena nivoa kreativnosti koju su dali svi anketirani ispitanici je 0,396, a medijana je 0,428). U nastojanju da se ovaj nalaz konkretizuje, preduzeta je analiza povezanosti grupišućih varijabli organizacione kreativnosti sa potencijalnim faktorskim varijablama organizacione kreativnosti.
\end{abstract}

Ključne reči: kreativnost, organizaciona efektivnost, creativna organizaciona klima

\section{Introduction}

Improvement of management effectiveness in the economic organizations in the front of organizational executives has been set up as priority task.

However, measuring effectiveness is not an easy task. Organization understanding, as well as choice of management effectiveness measuring method has experienced the conceptual changes in past few decades. Instead of generic organizational method, which in the science of management was considered as a paradigm during the first half of 20th century (Taylor's approach), as the response to the informational society challenges, new conceptual organizations appeared. (exp. virtual organizations) as well as appropriate models of measuring management effectiveness.

Examination of the application of these new approaches to identifying management effectiveness is very important scientific objective of empirical management research in the specific conditions of countries in transition. 
Arsenijević $O$. et al.: Relationship between organizational climate and management...

The subject of this research is the connection between management effectiveness in economic organizations of Vojvodina and creative organizational climate.

According to that, scientific objective of our research is checking one of the most widely used model of measuring management effectiveness - Baldrige's model, on which is based system of management quality incentives in USA.

Problem of this research can be expressed with following questions: Whether is possible that the company management in modern market conditions in AP Vojvodina, which has been designed as per traditional Taylor's model that started from the early stage of capitalism development, can be considered as effective? Are the organizations in AP Vojvodina, with characteristics of modern economic organizations (creative climate, elements of learning organization) showing the advantages in the terms of organizational effectiveness in comparing to organization that doesn't have those characteristics? How effective is management that is maintaining creative organizational climate? Can the level of organizational effectiveness in whole be increased by maintaining of creative organizational climate in the reality of economic organizations in Vojvodina?

\section{Previous researches}

Criteria of organizational and management effectiveness are in with relation with the understanding of nature evolution and organizational function (Baker, Branch, 2002). But, regardless of organization understanding, individual and the systems are the basic units of analyze in the organizational science. Each of these units can be viewed inside of the organization, within the external environment or in interaction with environment.

Depending of the corner of organization monitoring there is a question of defining the criteria of effectiveness. If the managers are seeing the organization as the machine for effective production of products or services, then managerial control is trying to maximize the production and standardize the products because of effectiveness. If, however, we look at the organization as a flow and transformation, then the main role of manager is to create and shape the context which can provide the corresponding forms of self-organization([Morgan, 1997).

One of the most used methods of the organizational effectiveness evaluation of Malcolm Baldrige (Baldrige National Quality Program, 2002), based on this basic, generic approach. Baldrige's seven results criteria - leadership, strategical planing, focus on customers and market, information's and analysis, focus on human resources, focus on processes and business results 
Arsenijević $O$. et al.: Relationship between organizational climate and management...

- include critical managerial and organizational functions identified $i$ the early management literature.

Last two decades were marked by discussions of the design of the organizations which allow that organization to work better, learn faster and changes easier (Kotter, 1996). Organizational design is made of many related elements, which are often categorized as structure, people, processes, awards and tasks or working systems that together can make unique organizational skills that are bringing competitive advantage (Quinn, 1988). Her attention has been moved from generic to organic organization and population, according to which managers needs to be leaders whose contribution should be to provide vision and direction in order to engage hearts and minds of employees, as a stakeholders and customers, and not to operate with critical generic functions of organization (Dessler, 2008).

Main role of management, according to that, is defined by simulating motivational practices, supporting creativity and innovations in the work of employees, customers and stakeholders, and providing of leaders improvement in the organization, to promote the success of organization (Kotter, Heskett, 1992; Wilson, Thomas, 2003).

The latest opinions are going the step further and indicate on how necessary is organizational effectiveness model appropriate to the specific requirements and objectives of special organization. Lorens i Lorsch introduced the term of contigency theory (Lorsch, 2012.) to show that different environments are setting the different demands to the organizations.

\section{Empirical research}

Research hypotheses. Starting from given theoretical assumptions, objects, problems and goals we have set the following research hypotheses:

The null hypothesis $\mathrm{HO}$ : There is no difference between the characteristics of the effectiveness of management in the economic organizations with different levels of the creative organizational climate.

Alternative hypothesis Ha1: There are significant differences between the characteristics of the effectiveness of management in the economic organizations with different levels of creative organizational climate.

By rejecting the null hypothesis and accepting the alternative we should identify those elements of creative organizational climate that contribute to improving the overall effectiveness of the management in the economic organizations in Vojvodina. 
Arsenijević O. et al.: Relationship between organizational climate and management...

\subsection{Type of research}

The given research has an empirical character. For the realization of field research as a basic methodological approach was used Survey method and a number of research instruments. The collected data further have been processed by the appropriate statistical procedure, presented and discussed.

\subsection{Population and sample}

The goal of the sampling was to provide a sample of 200 to 250 companies from the territory of AP Vojvodina and the corresponding sample of members of management of these organizations (approximately 300 to 400 people). It was anticipated to take the sample from the population of all enterprises in AP Vojvodina. The sample is identified by random drawing method of systematic sampling (every $n$-th from the list), provided that the original sample has 300 organizations (it is expected that $20-30 \%$ of organizations will not provide valid survey material). There has been a final sample of 224 companies with valid survey material. The sample is taken relying on the willingness of organization's management for cooperation. The process of interviewing was conducted in the period from September 2014 to January 2015.

In the identified organizations all the members of management and expert structures, primarily the supreme executive management, are defined as the subjects of interrogation. By the end of research, the sample consisted of 321 managers. Thus formed the sample allows conclusions on the level of reliability of $p<0.05$.

\subsection{Variables}

The main planned techniques of data collection were electronic questionnaire and interview by interviewers.

The main instrument of data collection was a questionnaire containing sections: Identification of the observation units and respondents; battery of questions with inventory characteristics of organizational effectiveness based on the approach of Baldridge Institute (measurement by Likert scale with five degrees); battery of questions for identifying climate of creativity in the organization; battery of questions on subjective preferences, life satisfaction and proactive attitude of members of the management of the respondent organizations.

For the purpose of measuring the level of organizational effectiveness of management an indicator to measure the absolute effectiveness was designed as well as a relative indicator of deviation level of organizational effectiveness from the corresponding level in EU enterprises. 
Arsenijević O. et al.: Relationship between organizational climate and management...

Indicators for each of the seven criteria of organizational effectiveness and the corresponding subcriteria are obtained as the average value from the questionnaire for the same organization (responses of the respondents from the same organization).

\subsection{Data processing}

The data are entered in the basic matrix and subjected to multiple checks (logic control, normality, requirements from the regression analysis, item analysis ...). All variables are subjected bivariant analysis.

In accordance with the prevailing nature of the data, statistical methods appropriate for categorial data were selected: non-parametric tests, chisquare test, logistic regression, path analysis and others.

\section{Research results}

\subsection{Reliability of the system variables}

Before approaches to data analysis, it is necessary to determine the extent to which the set of variables "affect" the construct that has been the basis of research, namely, the construct of organizational effectiveness and the construct of creativity. For the purpose of this testing was performed item analysis, and the reliability test was applied by calculating Cronbach's alpha.

The high value of Cronbach's alpha (Cronbach alpha: 0.966550) indicates the high reliability of the variables used to cover the constructs put in the basis of this research. The average correlation between variables is low $(r=0.00)$ which allows discrimination in identifying connection (relation) between some variables.

Detailed analysis of individual variables and of their contribution to the reliability of the set of pattern variables, indicate the existence of variables whose exclusion from the sample of variables increases Alfa value (33 variables), as well as the variables whose exclusion from the total sample of variables cause decline of the Alfa value (77 variables). The first category of variables has a lower significance for explaining the cognitive content to which the research is oriented, while the second category has a high significance.

The results of this test should be kept in mind while translating a set of variables to a limited set of factor variables. 
Arsenijević O. et al.: Relationship between organizational climate and management...

\subsection{Characteristics of respondents}

Before proceeding to the analysis of the results obtained by the survey, it is necessary to ascertain the reliability of drawing conclusions based on statistics that represent the normality of distribution of variables. If it turns out that the proper distribution of data with at least ordinal measuring scale is normal (Gaussian curve), then the more powerful parametric tests can be applied, and if this is not the case, it is necessary to apply the less powerful parametric tests. Results of parametric tests applied to data that do not meet the premise of normality can be taken as a guide to further analysis, but not as a reliable basis for concluding.

Table 1 - Variables of demographic characteristics of respondents

\begin{tabular}{|l|l|l|l|l|l|l|l|l|}
\hline & $\mathrm{N}$ & Mean & $\begin{array}{l}\text { Std. } \\
\text { Deviation }\end{array}$ & Coefficient of & Skewness & & Kurtosis & \\
\hline & Statistic & Statistic & Statistic & Variation & Statistic & $\begin{array}{l}\text { Std. } \\
\text { Error }\end{array}$ & Statistic & $\begin{array}{l}\text { Std. } \\
\text { Error }\end{array}$ \\
\hline POL2 & 317 & 1,59 & 0,49 & 30,81 & $-0,381$ & 0,137 & $-1,867$ & 0,273 \\
\hline DET3 & 318 & 2,53 & 0,69 & 27,27 & $-1,073$ & 0,137 & $-0,058$ & 0,273 \\
\hline SKOB4 & 315 & 2,72 & 0,46 & 16,91 & $-1,180$ & 0,137 & $-0,101$ & 0,274 \\
\hline STRSP5 & 320 & 2,11 & 1,11 & $\underline{52,60}$ & 2,416 & 0,136 & 18,335 & 0,272 \\
\hline RDIS6 & $\mathbf{3 2 1}$ & $\mathbf{1 , 5 0}$ & $\mathbf{0 , 5 2}$ & $\mathbf{3 4 , 6 6}$ & $\mathbf{0 , 2 0 9}$ & $\mathbf{0 , 1 3 6}$ & $\mathbf{- 1 , 4 8 9}$ & $\mathbf{0 , 2 7 1}$ \\
\hline & & & & & & & & \\
\hline $\begin{array}{l}\text { Valid N } \\
\text { (listwise) }\end{array}$ & 289 & & & & & & & \\
\hline
\end{tabular}

The variable Work experience RDIS8 meets the requirements of normality. Other variables do not meet this requirement, hence it must be borne in mind when selecting statistical tests.

The absence of normality of schedule for most variables limits the reliability of conclusions about uniformity of characteristics of respondent's attitude, that suggest coefficients of variation (except for the variable STRSP6, in which the deviation is the variability of the average values is over $50 \%$ ).

Gender composition of the sample deviates from the natural gender structure of the population, while the ratio of 40:60 in favor of male respondents can be considered satisfactory for the social circumstances of Serbia and Vojvodina.

Urban origin of respondents - Data indicate that $90 \%$ of respondents are of urban origin, while $10 \%$ come from the countryside. This arrangement of respondents is the result of deliberate sampling, appropriate to the requirements posed by the topic of this paper - research of modern management and its relationship to creativity. 
Arsenijević $O$. et al.: Relationship between organizational climate and management...

School education of respondents is one of the prerequisites of their ability to join into modern management processes, in particular for creating a creative organizational climate. Since as respondents are elected the members of the management structure, the data on their dominant higher education (over $70 \%$ of respondents with that level of school education) shows that the subjective composition of management in selected organizations is prepared for the tasks that modern management sets.

It is also noted that the representation of those with lower education level is negligible, only $0.6 \%$, while those with high school education at the level of about $25 \%$, a third of respondents have the highest qualifications (master's degree and doctorate).

Work experience of respondents shows that the respondents belong to the younger and middle generations of professional managers, with these two categories of respondents almost equal - $51 \%$ to $48 \%$. Members of the older generation, with over 20 years of experience, among them there are only three.

\subsection{Perceptions of professional development factors}

\section{Dimensions of professional development}

To the question "Which dimension you consider important for professional development?" three answers are offered:

1. Subjective - which is reflected in the distinctive abilities, selfconfidence, interests and attitudes, dedication and other personal characteristics of the individual;

2. Objective - which is reflected in the objective conditions for professional advancement: the existence of jobs and positions that vary in complexity, responsibility and organizational level;

3. They are equally important.

The analysis of the responses indicates that respondents largely attributed equal importance to subjective and objective dimension of professional development (three quarters of the received responses). This response can be interpreted as an expression of insufficient grasp of the respondents in the specific character of the aforementioned dimensions of professional development. Based on the responses of a small number of respondents who gave priority to one of the two dimensions, it can be concluded that the relatively higher share of those who turn to subjective assumptions professional development - 15\%, concerning the personality of a person and that he can influence, a much smaller proportion of those who give priority to objective factors - $9 \%$, on which he can not influence. 
Arsenijević $O$. et al.: Relationship between organizational climate and management...

Characteristics of respondents relevant to successful professional development - Question asked "Within the following list, circle the number in front of the three traits that you consider most important for successful professional development of individuals" had the task for respondents to indicate priority personality traits that contribute to successful professional development. Respondents, choosing between eleven properties offered, pulled three characteristics to which they give priority. A list of offered features was:

1. High intelligence

2. A beautiful physical appearance

3. Gender affiliation

4. Social origin and position of parents

5. Good attitude towards people

6. Obedience and criticism pervades

7. Moral integrity and independence

8. Work

9. Expertise

10. Relying on the connections

11. Enterprising.

Analysis of the results showed that the three most important characteristics for successful professional development of individuals are:

1. High intelligence $-37.4 \%$

2. Work $-44.9 \%$

3. Expertise - 49.2\%.

The following capabilities can be added:

- Integrity and independence - 22.1\% and

- Entrepreneurship - 26.8\%.

The smallest significance the respondents attributed to the following structural characteristics: gender, social origin and position of parents, and relying on connections.

On the basis of these statements can be concluded that the majority of respondents attaches priority to the subjective characteristics that are subject to change, if an individual possesses the motivation for such a change, and cultural brakes do not hinder the implementation of necessary changes in individual behavior.

Willingness to engage in improving professional development - On the question "How much are you willing for intensive engagement (to work, further training, travel) in order to improve your professional development?" the offered answers were: 
Arsenijević O. et al.: Relationship between organizational climate and management...

1. I am not ready at all

2. Mainly I a not ready

3. I am and I am not ready

4. Usually I am ready

5. I am quite ready.

Insight into the obtained data shows that three quarters of respondents chose answers 4 and 5 on the scale - "Usually I am ready" and "I am quite ready", leading to the conclusion that the organizations analyzed in this paper are open to learning, which is an essential condition for developing creative organizational climate.

\section{The analysis of correlations between variables}

From the correlation analysis follows an indicative conclusion that with the growth of professional qualifications there is observed decreasing willingness to efforts to further improve professional development $(r s p=0.147$ to $p$ $<0.012$ ). With the rise of urbanity environment in which the respondents raised in childhood and early youth there is observed growing willingness to further efforts for the improvement of professional ( $r s p=0.122$ to $p<0.037$ ). The same relationship is noted in positively correlated levels of school education and readiness for additional professional enhancement ( $r s p=0.123$ to $p<0.037)$.

\subsection{The respondents' satisfaction with the outcome and conditions for professional development}

Respondents were asked about their satisfaction with the outcome and conditions for professional development.

1. Satisfaction with personal professional development.

2. The satisfaction with general social conditions for professional development of professionals and managers.

3. Satisfaction with the care devoted in your organization to developing and motivating staff.

4. Satisfaction with possibility to gain new professional and managerial skills through various educational programs.

Satisfaction with personal professional development is aspect of the relationship of respondents to ourselves that, in $50 \%$ of subjects showed the highest positive attitude (average level of 3.93 and relatively the smallest CV (coefficient of variation) $=22.13 \%$ ) and in the other $25 \%$ the highest level of satisfaction. Only $6.2 \%$ indicate dissatisfaction in this regard.

The respondents indicate opposite attitude towards the general social conditions for professional development of professionals and managers (the 
Arsenijević $O$. et al.: Relationship between organizational climate and management...

average level of 2.86 and relatively the highest $C V=39.51$ ) provided that the proportion of respondents who indicate dissatisfaction with social conditions significantly higher $(36.1 \%)$ of those who express a greater satisfaction (28.7\%).

The respondents' satisfaction with the situation in the organization, especially with the management attitude towards developing and motivating staff, occupies a central position on the scale of satisfaction (average level was 3.42 with $\mathrm{CV}=33.04 \%$ ). It should be noted that a significant percentage of respondents was undecided or dissatisfied $(47.7 \%)$ in the evaluation of personnel policy in their organizations.

The same can be said for the level of satisfaction of respondents with respect to the possibility that through a variety of educational programs, acquire new professional and managerial skills (with an average level of $3.40, \mathrm{CV}=33.52$ ). However, prevail from $51.4 \%$ respondents having high satisfaction concerning the possibility of educating.

The analysis of correlations between variables

From the analysis of correlations between variables it is observed a high positive correlation between the variables "Satisfaction with attention that the organization dedicated to the development and motivation of staff" and "Satisfaction with possibility to acquire new professional and managerial skills through various educational programs". It is also noted a strong correlation between the variables "satisfaction with their personal professional development" and "satisfaction dedicated to the development and motivation of staff in the organization". It can be concluded that the respondents perceived the attention which the organization dedicated to the development and motivation of personnel as an important factor for creating a climate of satisfaction in their organizations.

\subsection{Characteristics of the respondent's personalities}

Respondents were asked ten questions with implicit introspective assessments of their own personality characteristics:

1. The tasks and activities, whose outcome depends on my ability and effort, are attractive for me.

2. When I think about my success I more care to satisfy my internal criteria, than to comparing with others.

3. And when I'm not interested in an area, I try to do my best.

4. I'm working on solving problems, although they require a greater effort.

5. Dedicate some time a problem for me is wasted time. 
Arsenijević O. et al.: Relationship between organizational climate and management...

6. Problems that require a lot of effort and time attract me.

7. The tasks or activities that require independence and responsibility fit to me.

8. My requirements to myself, in terms of volume and quality of work, are within the limits of what I can, I know and I want.

9. I am indiferent if I do not accomplish my duties.

10. I have willpower the boring obligation to do well and on time.

Respondents were asked to express their assessment using the following measuring scale:

1. Never does not apply to me,

2. Almost never does not apply to me,

3. Sometimes it refers to me,

4. Almost always it refers to me, and

5. Always refers to me.

The highest level of estimate and mutual consent (CV) respondents showed when answering the question 7. "The tasks or activities that require independence and responsibility fit to me" (this feature is identified with $81.6 \%$ of respondents) and 8. "My requirements to myself, in terms of volume and quality of work, are within the limits of what I can, I know and I want" $(82 \%$ of respondents).

Independence and accountability are important features of creative personality.

Orientation on activities that rely on skills and efforts, as characteristic of its personality, has identified $73.5 \%$ of respondents. About three-quarters of respondents $(75 \%)$ identified at itself characteristic of introversion - reliance on self-evaluation without comparing their effects and success with others.

The tendency to increased investment of effort in solving the tasks at work has identified by themselves the $77.6 \%$ of respondents.

A set of personal characteristics of the respondents identified by themselves at the slightly lower level, but still at the level of "almost always refers to me", refers to properties that contain variables contained in questions 3, 5, 6 and 10.

Self-control in a situation where the job requires performing annoying, repulsive and uninteresting tasks is identified by $68.9 \%$ of respondents, and more than one quarter of respondents (28\%) did not identify with this feature.

Another characteristic of self-control in a situation where the task does not belong to the circle of respondent's interests, also was identified by a high 
Arsenijević $O$. et al.: Relationship between organizational climate and management...

percentage of respondents - $71 \%$. But over a quarter (27.8\%) of respondents failed to identify themselves with this kind of self-control.

Around the question implying a negative attitude toward the perseverance of problem solving, contained in the variable "Devoting long time to a problem is wasted time for me", the sample of respondents was divided into two approximately equal subsets: $49.9 \%$ of respondents identify themselves with the reluctance of solving the long-term problems, and $48.7 \%$ those noted in themselves such a long-term commitment to resolve problems.

The same question raised in a positive sense ("Problems that require a lot of effort and time attract me") differentiated the sample of respondents to $57.6 \%$ of those who identify themselves with the long-term tendency to solve problems and $45 \%$ of those who had not recognize such preference on themselves.

And finally, $75.9 \%$ of respondents refused to identify themselves with indifference to the accepted obligations, contained in the variable "I am indiferent if I do not accomplish my duties". On this issue among the respondents is the largest non-compliance, as evidenced by the relatively highest coefficient of variation of $63.40 \%$.

\subsubsection{Correlation of subjective characteristics}

Analysis of correlation within the battery subjective characteristics of respondents shows that the strongest positive correlation exists between variable "And when I'm not interested in an area, I try to do my best" and variable "I'm working on solving problems, although they require a greater effort".

The variable "The tasks and activities, whose outcome depends on my ability and effort, are attractive for me" has a strong correlative association with other variables of subjective characteristics of respondents:

- When I think about my success I more care to satisfy my internal criteria, than to comparing with others.

- I'm working on solving problems, although they require a greater effort.

- The tasks or activities that require independence and responsibility fit to me.

- My requirements to myself, in terms of volume and quality of work, are within the limits of what I can, I know and I want. 
Arsenijević O. et al.: Relationship between organizational climate and management...

\section{Factors of levels of organizational effectiveness}

Respondents, whose answers we analyzed in the previous chapter, originate from 224 organizations from 12 different settlements in Vojvodina. In this chapter, we put the focus of our attention on these organizations, attempting thereby to determine their characteristics, as a system of economic activities that are managed.

\subsection{Level of Management Effectiveness}

Analysis of organizational effectiveness required the grouping of organizations involved in the research sample into categories, according to the level of points calculated on the basis of Baldridge test. This test predicts 1000 points to organizations that achieve the maximum points for all seven measurement criteria. Classifying all organizations according to the percentile points achieved (in percentage to the maximum possible points) we obtained distribution shown in Table 2. On the basis of percentiles, a regrouping to the quantiles was performed and in such a way were obtained four groups of organizations, whose level of effectiveness of management is expressed by ranges of points (BALGRU4C variable). Further, grouping organizations into two groups (above and below the median score) we obtained variable BALGRU2C.

Table 2. Organisations according actual points

\begin{tabular}{|c|c|c|c|c|c|c|}
\hline & & SVEUKC & & & Group & Range of points \\
\hline $\mathrm{N}$ & Valid & 321 & $\mathrm{~N}$ & 321 & & \\
\hline & Missing & 0 & & 0 & & \\
\hline Percentiles & 10 & 52.90970 & Quartiles & & 1 & 0 to 61.332 \\
\hline & 20 & 60.00750 & & & & \\
\hline & 25 & 61.33188 & & 61.33188 & & \\
\hline & 30 & 64.44331 & & & 2 & 61.333 to 71.954 \\
\hline & 40 & 68.43375 & & & & \\
\hline & 50 & 71.95375 & Median & $\mathbf{7 1 . 9 5 3 7 5}$ & & \\
\hline & 60 & 75.00000 & & & 3 & 71.955 to 78.595 \\
\hline & 70 & 76.85938 & & & & \\
\hline & 75 & 78.59508 & & 78.59508 & & \\
\hline & 80 & 82.28750 & & & 4 & 78.596 to 100 \\
\hline & 90 & 86.94875 & & & & \\
\hline
\end{tabular}


Arsenijević O. et al.: Relationship between organizational climate and management...

\subsubsection{Analysis of relation of grouping variables of management effectiveness with potential factorial variables of management effectiveness}

Table 3. Share of organizations with different levels of effectiveness of the management in surveyed cities from AP Vojvodina

\begin{tabular}{|c|c|c|c|c|c|}
\hline & \multicolumn{4}{|c|}{ BALGRU4C } & \multirow[b]{2}{*}{ Total } \\
\hline & 1 & 2 & 3 & 4 & \\
\hline $\begin{array}{l}\text { MES1 Apatin Count } \\
\% \text { within MES } 1 \\
\% \text { within BALGRU4C }\end{array}$ & & & & $\begin{array}{l}1 \\
100.0 \% \\
1.3 \%\end{array}$ & $\begin{array}{l}1 \\
100.0 \% \\
.3 \%\end{array}$ \\
\hline $\begin{array}{l}\text { Bačka Palanka Count } \\
\% \text { within MES } 1 \\
\% \text { within BALGRU4C }\end{array}$ & $\begin{array}{l}1 \\
50.0 \% \\
1.3 \%\end{array}$ & & $\begin{array}{l}1 \\
50.0 \% \\
1.3 \%\end{array}$ & & $\begin{array}{l}2 \\
100.0 \% \\
.6 \%\end{array}$ \\
\hline $\begin{array}{l}\text { Inđija Count } \\
\% \text { within MES } 1 \\
\% \text { within BALGRU4C }\end{array}$ & & & $\begin{array}{l}1 \\
100.0 \% \\
1.3 \% \\
\end{array}$ & & $\begin{array}{l}1 \\
100.0 \% \\
0.3 \% \\
\end{array}$ \\
\hline $\begin{array}{l}\text { Kikinda Count } \\
\% \text { within MES } 1 \\
\% \text { within BALGRU4C }\end{array}$ & & $\begin{array}{l}1 \\
50.0 \% \\
1.2 \%\end{array}$ & $\begin{array}{l}1 \\
50.0 \% \\
1.3 \%\end{array}$ & & $\begin{array}{l}2 \\
100.0 \% \\
0.6 \%\end{array}$ \\
\hline $\begin{array}{l}\text { Novi Sad Count } \\
\% \text { within MES } 1 \\
\% \text { within BALGRU4C }\end{array}$ & $\begin{array}{l}38 \\
17.8 \% \\
47.5 \%\end{array}$ & $\begin{array}{l}62 \\
29.0 \% \\
73.8 \%\end{array}$ & $\begin{array}{l}58 \\
27.1 \% \\
75.3 \%\end{array}$ & $\begin{array}{l}56 \\
26.2 \% \\
70.0 \%\end{array}$ & $\begin{array}{l}214 \\
100.0 \% \\
66.7 \%\end{array}$ \\
\hline $\begin{array}{l}\text { Pećinci Count } \\
\% \text { within MES } 1 \\
\% \text { within BALGRU4C }\end{array}$ & & & $\begin{array}{l}4 \\
100.0 \% \\
5.2 \%\end{array}$ & & $\begin{array}{l}4 \\
100.0 \% \\
1.2 \%\end{array}$ \\
\hline $\begin{array}{l}\text { Ruma Count } \\
\% \text { within MES } 1 \\
\% \text { within BALGRU4C }\end{array}$ & $\begin{array}{l}1 \\
100.0 \% \\
1.3 \%\end{array}$ & & & & $\begin{array}{l}1 \\
100.0 \% \\
.3 \%\end{array}$ \\
\hline $\begin{array}{l}\text { Sremska Mitrovica Count } \\
\% \text { within MES } 1 \\
\% \text { within BALGRU4C }\end{array}$ & $\begin{array}{l}32 \\
44.4 \% \\
40.0 \%\end{array}$ & $\begin{array}{l}16 \\
22.2 \% \\
19.0 \%\end{array}$ & $\begin{array}{l}5 \\
6.9 \% \\
6.5 \% \\
\end{array}$ & $\begin{array}{l}19 \\
26.4 \% \\
23.8 \%\end{array}$ & $\begin{array}{l}72 \\
100.0 \% \\
22.4 \%\end{array}$ \\
\hline $\begin{array}{l}\text { Subotica Count } \\
\% \text { within MES } 1 \\
\% \text { within BALGRU4C }\end{array}$ & & & $\begin{array}{l}1 \\
100.0 \% \\
1.3 \%\end{array}$ & & $\begin{array}{l}1 \\
100.0 \% \\
0.3 \%\end{array}$ \\
\hline $\begin{array}{l}\text { Šid Count } \\
\% \text { within MES } 1 \\
\% \text { within BALGRU4C }\end{array}$ & $\begin{array}{l}5 \\
35.7 \% \\
6.3 \%\end{array}$ & $\begin{array}{l}1 \\
7.1 \% \\
1.2 \%\end{array}$ & $\begin{array}{l}5 \\
35.7 \% \\
6.5 \%\end{array}$ & $\begin{array}{l}3 \\
21.4 \% \\
3.8 \%\end{array}$ & $\begin{array}{l}14 \\
100.0 \% \\
4.4 \%\end{array}$ \\
\hline $\begin{array}{l}\text { Vršac Count } \\
\% \text { within MES } 1 \\
\% \text { within BALGRU4C }\end{array}$ & $\begin{array}{l}3 \\
50.0 \% \\
3.8 \%\end{array}$ & $\begin{array}{l}3 \\
50.0 \% \\
3.6 \%\end{array}$ & & & $\begin{array}{l}6 \\
100.0 \% \\
1.9 \%\end{array}$ \\
\hline $\begin{array}{l}\text { Zrenjanin Count } \\
\% \text { within MES } 1 \\
\% \text { within BALGRU4C }\end{array}$ & & $\begin{array}{l}1 \\
50.0 \% \\
1.2 \%\end{array}$ & & $\begin{array}{l}1 \\
50.0 \% \\
1.3 \%\end{array}$ & $\begin{array}{l}2 \\
100.0 \% \\
0.6 \%\end{array}$ \\
\hline $\begin{array}{l}\text { Total Count } \\
\% \text { within MES } 1 \\
\% \text { within BALGRU4C }\end{array}$ & $\begin{array}{l}80 \\
24.9 \% \\
100.0 \%\end{array}$ & $\begin{array}{l}84 \\
26.2 \% \\
100.0 \%\end{array}$ & $\begin{array}{l}77 \\
24.0 \% \\
100.0 \%\end{array}$ & $\begin{array}{l}80 \\
24.9 \% \\
100.0 \%\end{array}$ & $\begin{array}{l}321 \\
100.0 \% \\
100.0 \%\end{array}$ \\
\hline
\end{tabular}

Since we implemented a process Crosstab, we can note a very strong relationship of organizations with the level of management effectiveness - 
Arsenijević O. et al.: Relationship between organizational climate and management...

Hikv $=69.692, \mathrm{df}=36, \mathrm{p}=0.001$. This relation is very strong $-\mathrm{C}=0.422$ with $p=0.001$, with a weak negative correlation (Spearman $r=0.124, p=0.026$ ). Lambda test leads to the conclusion that the organization determine the level of management effectiveness to a greater extent than the reverse (if variable SVEUKUC take for a dependent, the percentage reduction in errors of inference is $12.7 \%$, while the reverse connection reduce this error by $0.0 \%$, in both cases at $p=0.000$ ).

Regarding the cities of analyzed organizations, we can note significant fluctuations of management effectiveness (table 3 - share of organizations with low effectiveness (group 1) in Šid was $35.7 \%$ and in Sremska Mitrovica $44.4 \%$, which is significantly more than the share of such organizations in Novi Sad, where it is $17.8 \%$.

Analysing the relation between seven dimensions of Baldrige model to measure the management effectiveness, we can note that none of the variables does not meet the requirements of schedule normality. Therefore, with the necessary caution, one can conclude that in these variables respondents attitudes show no significant deviation from the average attitudes, that reflect the estimates given by all respondents (coefficients of variation ranging from $20 \%$ to $25 \%$ of average value points).

Table 4. Correlation seven dimensions of Baldrige model to measure the effectiveness of management

\begin{tabular}{|c|c|c|c|c|c|c|c|c|}
\hline & $\begin{array}{c}\mathrm{N} \\
\text { Statistic }\end{array}$ & $\begin{array}{c}\text { Mean } \\
\text { Statistic }\end{array}$ & $\begin{array}{c}\text { Std. } \\
\text { Deviation } \\
\text { Statistic }\end{array}$ & $\begin{array}{c}\text { Coefficient } \\
\text { of variation }\end{array}$ & Skewness & & $\begin{array}{c}\text { Kurto } \\
\text { sis }\end{array}$ & \\
\hline & & & & & Stastistic & $\begin{array}{c}\text { Std } \\
\text { Error }\end{array}$ & $\begin{array}{c}\text { Statis } \\
\text { tic }\end{array}$ & $\begin{array}{c}\text { Std. } \\
\text { Error }\end{array}$ \\
\hline VODSTVO1 & 321 & 1.08 & 0.26 & 24.35 & -0.494 & $\begin{array}{c}0.13 \\
6\end{array}$ & 1.715 & 0.271 \\
\hline STRATPL2 & 321 & 2.49 & 0.61 & 24.40 & -0.690 & $\begin{array}{c}0.13 \\
6\end{array}$ & 0.920 & 0.271 \\
\hline TRZISTE3 & 321 & 1.59 & 0.33 & 20.44 & -1.106 & $\begin{array}{c}0.13 \\
6\end{array}$ & 2.725 & 0.271 \\
\hline MERENJE4 & 321 & 1.31 & 0.28 & 21.05 & -1.175 & $\begin{array}{c}0.13 \\
6\end{array}$ & 2.724 & 0.271 \\
\hline LJUDRES5 & 321 & 1.25 & 0.31 & 24.88 & -1.102 & $\begin{array}{c}0.13 \\
6\end{array}$ & 1.793 & 0.271 \\
\hline PROCES6 & 321 & 1.29 & 0.28 & 21.56 & -1.245 & $\begin{array}{c}0.13 \\
6\end{array}$ & 3.405 & 0.271 \\
\hline REZULT7 & 321 & 0.88 & 0.17 & 19.09 & -1.431 & $\begin{array}{c}0.13 \\
6\end{array}$ & 4.744 & 0.271 \\
\hline $\begin{array}{c}\text { Valid N } \\
\text { (listwise) }\end{array}$ & 321 & & & & & & & \\
\hline
\end{tabular}

Comparing the seven dimensions of management effectiveness, we note (Table 4) that the respondents, in general, negatively rated all the dimensions of management effectiveness by worded disagreement with positive attitudes. 
Arsenijević $O$. et al.: Relationship between organizational climate and management...

Smaller variability in assessments is observed in dimension "Strategic planning" (STRATPL2), "Attitudes towards the market" (TRZISTE3) (relatively the most positive score) and "Operating results" (REZULT7) (relatively the most negative assessment with the least discrepancy in assessments among the respondents).

Leadership by the respondents was rated negative: score 1 - "I strongly disagree". Detailed analysis of the attitudes that constitute this dimension reveals that the majority of these respondents agree (score 3-point Likert scale). Relatively best score was attributed to the offered position MISIJA1 of knowledge of the organization's mission. Chi-square test of association of all variables of this dimension with the grouping variable allows the rejection of the null hypothesis at $p=0.00$.

Strategic planning is the dimension of effective management, which the respondents rated by the least relatively positive assessment (grade 2 - "I do not agree"). Detailed analysis shows that respondents are not confident in the assessment of them participation in planning in their organization PLAN8 (average score 3 ), with the pronounced mismatch in the assessments (OR = 34.49). Participation in the planning of their own working conditions NAŠRE10 received a relatively favorable assessment of the respondents: 4 - "I agree". Chi-square test of association of all variables of this dimension with the grouping variable also allows the rejection of the null hypothesis at $p=0.00$.

Orientation to customers and the market, according to estimates of the respondents, is present in their relationships: score 4 - "I agree". Respondents gave relatively less favorable assessment to the powers at their disposal to establish relationships with clients, with the more pronounced consent of the respondents in this evaluation $(\mathrm{CV}=27.89 \%)$. Chi-square test of association of all variables of this dimension with the grouping variable allows the rejection of the null hypothesis at $p=0.00$.

Measurement, analysis and knowledge management, as the basis of the current stage of the economy of knowledge and information, in the observed organizations were deemed the existing: grade 4 - "I agree". Respondents gave relatively low grade, with significant mismatch, to the item ORGDL21 that measures the level of information in organizations. Chi-square test of association of all variables of this dimension with the grouping variable allows the rejection of the null hypothesis at $p=0.00$.

Orientation to human resources, according to the assessment of the respondents, is present in the surveyed organizations: score 4 - "I agree". Relatively favorable assessment is given to the attitude of cooperation and teamwork in the surveyed organizations (with relatively largest approval of respondents $\mathrm{CV}=22.22 \%$ ). Chi-square test of association of all variables of 
Arsenijević $O$. et al.: Relationship between organizational climate and management...

this dimension with the grouping variable here also allows for the rejection of the null hypothesis at $p=0.00$.

Process management has been rated with 4 - "I agree", with no major inconsistencies in the assessments among the respondents. Chi-square test of association of all variables of this dimension with the grouping variable here also allows for the rejection of the null hypothesis at $p=0.00$.

Operating results were evaluated by 4 - "I agree", with differences among respondents slightly more pronounced in the variable POMAZ39 on the participation of the respondents in the communities in which they live - CV = $33.33 \%$. Chi-square test here allows the rejection of the null hypothesis at $p=$ 0.00 .

For further analysis in accordance with the research hypothesis was allocated a narrower set of variables with significant relations with the main grouping variable of of management effectiveness level. Given the nature of the variables, the extraction process of significant variables was relied on the use of Spearman's rank correlation.

Analysis of organizational creativity required grouping of respondents included in the sample into categories, according to the processes of the values attributed to all opinions/statements calculated on the basis of the scale applied in the questionnaire. Variable "nivokreat" is obtained by calculating the sum of the values assigned by each respondent to all claims from the questionnaire on creativity. However, this variable measures the attitudes of respondents about the level of creativity of organizations in which these individuals act. For this research the assessment of the level of creativity in organization is important, so it was necessary to establish an indicator of the level of creativity based on the average score of all surveyed respondents from the same organization. To this end, we calculated average values for more respondents in the same organization (for most organizations with one respondent we retained the individual values), and in this way we obtained the variables "KREORG" and "kreorg_rng" (ranking organizations in comparison to the average value of the variable "KREORG", where the value 100 represents the average value for all organizations.

Bearing in mind that the average score of creativity level, given by all respondents is 0.396 (median 0.428), it can be concluded that in the sample of observed organization organizational creativity has "zero" level, while ideas and behavior inherent to creative organizational climate just born. 
Arsenijević O. et al.: Relationship between organizational climate and management...

\section{Concluding remarks}

The reliance of this study on two world-verified research instruments of management effectiveness and organizational creativity contributed to the high reliability of samples of variables which confirms the result of item analysis - a high value of Cronbach's alpha $=0.967$, and leads to the conclusion about the high reliability of the variables used for the inclusion of constructs placed on the basis of this research.

The key finding of this study can be expressed by the following conclusion: in a sample of observed organization the level of organizational creativity is at zero level. Ideas and behaviors inherent to creative organizational climate only born (average rating of level of creativity that all surveyed respondents gave was 0.396, and the median is 0.428). In an effort to concretize this finding, correlation analysis was undertaken between grouped variables of organizational creativity and potential factorial variables of organizational creativity.

The analysis led to the conclusion that there is a relation between organizations and the level of organizational creativity. This relation is strong with the weak negative correlation. Lambda test leads to the conclusion that the level of organizational creativity in higher degree depends of organization than vice versa. This finding is significant because it points to the role of management as a subject of creating a creative organizational climate. This climate is not born of itself, from the spontaneous initiative of employees, but also represents the interest and action of leading cadres of the organization, especially the top management.

Comparing the results of presented empirical analysis with theoretical expectations, formulated in theoretical models, allows to conclude that the basic hypothesis was confirmed and that in reality there is a relation between embryonic elements of creative organizational climate and effectiveness of management in the surveyed organizations in AP Vojvodina. By applying multiple methods of statistical tests it is confirmed that there is a weak relation between creative organizational climate and level of management effectiveness in the analyzed sample of organizations.

On the basis of this evidence, in the contemporary circumstances of Vojvodina the management of economic organizations designed according to the traditional Taylorist model from the early stage of development of capitalism can not be considered effective. In a small number of organizations in Vojvodina with the characteristics of modern economic organizations can be seen benefits in terms of organizational effectiveness in relation to the organization without such characteristics. Management that nurtures creative organizational climate, although it is rarely represented, is more effective than 
Arsenijević O. et al.: Relationship between organizational climate and management...

most of the organizations in which the prevailing climat of conflicts in interpersonal relationships, dysfunctional debates and disputes as well as a lack of willingness to accept the risk of change.

\section{References}

Baker, K., \& Branch, K. M. (2002). Concepts underlying organizational effectiveness: Trends in the organizationand management science literature. Management Benchmark Study. USA: Office of Planning \& Analysis.

Department of Energy Baldrige National Quality Program. (2002). Malcolm Baldrige national quality award 1990 winner: Federal Express Corporation. Retreived June 25, 2005 from http://www.quality.nist.gov/FederalExpress_90.htm

Dessler, G., (2008). Framework for Human Resource Management, A, 5/E, Florida International University Publisher: PrenticeHall Copyright: 2009

Kotter, J., (1996). Leading Change, Boston: Harvard Business School press.

Kotter, J., Heskett, J., (1992). Corporate Culture and Performance, New York, The Free Press

Lorsch, Jay W. (2012). The Future of Boards: Meeting the Governance Challenges of the Twenty-First Century. Boston, MA: Harvard Business Review Press.

Morgan, G., (1997). Images of Organization, Sage Publications, London.

Quinn, R. E., (1988). The Competing Values Model: Redefining Organizational Effectiveness and Change. Beyond Rational management: Mastering the Paradoxes and Competing Demands of High Performance, San Francisko, CA: Jossey-Bass

Wilson, Thomas A., (2003). Innovative Reward Systems for the Changing Workplace, Library of Congress Publication Data 